\title{
The Use of Cultural Filter to Achieve Functional Equivalence in English - Indonesian Translation of Dindal's Chicken Little: The Sky is Falling
}

\author{
Angga Karismawati ${ }^{\bowtie}$, Issy Yuliasri, Rudi Hartono \\ Universitas Negeri Semarang, Indonesia
}

\begin{abstract}
Article Info
Abstract

Article History:

Recived 29 December

2020

Accepted 20 February

2021

Published 20 June

2021

The study aims to explain the implementation of cultural filter through the House's dimensions (2015), as well as to explain the achievement of functional equivalence of children comic Chicken Little: The Sky is Falling. This study belongs to a descriptive qualitative study. The research was conducted by analyzing the dimensions of directness versus indirectness, orientation towards other versus orientation towards self, orientation towards addressees versus orientation towards content, implicitness versus explicitness, verbal routines versus ad-hoc formulation. The findings reveal that there are 190 cultural filters

Keywords: Children comic, cultural filter, found within the comic. There are 111 from orientation towards addressees versus orientation towards content, implicitness versus explicitness is 31 , directness versus indirectness is 30 , verbal routines versus ad-hoc formulation functional equivalence, House's dimensions are 15 , and the last is 3 from orientation towards other versus orientation towards self. On the other hand, out of 190, 15 sentences are identified as nonequivalence. In accordance with the result, the translator successfully applies cultural filter in order to reduce the cultural gap between SL and TL. Besides, the findings also suggest that cultural filter supports the achievement of functional equivalence of the translation.
\end{abstract}

E-mail: anggakarismawati@gmail.com 


\section{INTRODUCTION}

As a means of communication, translation always deals with languages and cultures. It becomes a solution to overcome the language gap in communication (Ismail \& Hartono, 2016). Indeed, they are inseparable as they define communication style of people around the world. Prasetyo and Nugroho (2013) adds that "a language is the cultural and personal expression of the speaker so that the language influences how the speaker perceives the world" (p. 1).

Translation is the act of rendering the language and also negotiating the cultures of SL and TL (Bassnett, 2002). However, interpreting SL as well as the culture was hard to do especially if the target readers are children. The lack of understanding about other languages or cultures should be the main concern to the translator. One of translation projects that children can enjoy is comics. Comic seems like a simple literary text because of its short sentences or phrases, however, it still needs consideration for the translator to create the same short texts in the TL. Furthermore, the translator should bring the same feeling to the target readers as if they read the original version. Besides translating one language to another language, translating comics also deals with socio-cultural of two different languages. It is strengthened by $\mathrm{Hu}(2000)$ who states that "translation of fiction is much more complicated than the translation of other genres, as it deals not only with bilingual, but also bi-cultural and bi-social transference" (p. 1). In addition, Yuliasri (2017) adds that during the process of translation, "the translators have to manipulate the text to be acceptable by the target readers and parents because not all aspects of Western culture are acceptable in Indonesia" (p. 105). Therefore, "translating literary works (prose fiction in particular) is more difficult than translating types of nonliterary texts as if translating literature, a translator must not only have the ability of bilingual but also have insight both sociocultural resources and sociocultural goals"
(Hartono, 2015, p. 186). It is required for the translator to acquire not only language systems, but also cultural knowledge of two languages. In other words, "the role of the translator is trying his/her best to overcome any cultural problems that may affect the transference of the meaning from the SL culture to the TL culture" (Kuncoro \& Sutopo, 2015, p. 9).

As the study presents how to deal with cultural differences in a translation, House $(2015,2016)$ introduces the concept namely cultural filter. "It is capturing socio-cultural differences in expectation norms and stylistic conventions between the source and target linguistic-cultural communities" (House, 2015, p. 68). Further, House (2016) also explains that "assumptions of cultural difference should be carefully examined before any change in the source text is undertaken, in order to achieve functional equivalence" (p. 82). A translator can overcome the cultural differences between the source text and target text. By doing so, the target readers will not aware of the occurrence of source culture at all. Furthermore, a cultural filter is closely related to covert translation. "Covert translations are not culture-specific but rather of potentially equal concern for members of different cultures" (Baumgarten et al., 2004, p. 84). Therefore, it is obvious that the idea of covert translation supports cultural filter which is done by addressing the target culture audience to achieve functional equivalence. Achieving equivalence is important to overcome cultural differences (Lovihandrie et al., 2018, p. 210). It is strengthened by Sari and Yuliasri (2017) who state that "the translation process is needed to obtain a high quality of translation in target language or at least equal with the source language" (p. 103)."

"Equivalence refers to a strategy that describes the same situation by using completely different stylistic or structural methods for producing equivalent texts" (Vinay \& Dalbernet, 2000, p. 52). Meanwhile, in connection with the theory of cultural filter, functional equivalence arises as one of the indicators of the strategy. Dynamic equivalence or functional equivalence is firstly introduced 
by Nida (1964). Nida (1964) further explains that "the relationship between receptor and message should be substantially the same as that which existed between the original receptors and the message" (p. 159). "Functional equivalent focuses on producing "the closest natural equivalent" of the source language message and aims at eliciting "substantially the same response" between source text readers and target text readers" (Yinhua, 2011, p. 1255). Indeed, naturalness is one of the keys to achieve equivalence so that a translation product can be accepted by readers. Besides, finding the closest meaning is also important to avoid non-equivalent meaning in translation work (Wijayanti \& Mirahayuni, 2014).

There have been several researchers writing about related studies. Most of the previous studies talked about how the translator deals with cultural filters during the process of translation. They were Baumgarten, House, and Probst (2004), House (2006), Tempel and Thije (2010), Luonua (2013), and Yang and Yen (2017). They brought cultural filter as their main focus of study in order to expose the result of cultural adjustment between Source Text and Target Text. Tempel and Thije (2010) particularly discussed the question of whether House's theory on a cultural filter can be applied to the study of the appreciation of multilingual audio tours.

Furthermore, Yuliasri and Hartono (2014), Windawati (2015), Xu (2015), Sudirman (2016), Alfaori (2017), Rupiah and Hartono (2017), Afifah, Hartono, and Yuliasri (2018), and Oktaviani, Hartono, and Sutopo (2018) revealed the translation strategies and methods of the texts and how they result in the equivalence level. Besides equivalence, a translation product could result in nonequivalence with some possible reasons. Therefore, it triggered some researchers to investigate it from a certain level by identifying and explaining the strategies how to deal with it. Mujiyanto (2011), for instance, argued that translation problems occur due to the differences in the grammatical features between the two languages. Later, he investigated formal nonequivalence that appears in the translation of behavioral clauses.

Since the study took a children's comic as the object, the researcher found out Bongco (2013) as well as Altenberg and Owen (2015) talking about the problems of comic translation as well as the strategies or procedures to overcome those matters. Yuliasri (2016) conducted research about humorous utterances in Donald Duck comics. Humor sometimes poses a problem for a translator as it portrays different cultures between SL and TL. Meanwhile, some researchers like McAllister, Sewell, and Gordon (2001), Hidayat and Zpalanzani (2011), Koponen (2014), and Weissbrod and Kohn (2015) also found out the ideology, wordplay, translation strategies, and techniques used in comics.

Finally, this study also deals with cultural differences between two languages by referring to each characteristic of language. What makes it different lies in House's theory as a guideline to compare the implementation of cultural differences. In the end, the translator's choice regarding the ideology and the causes of non-equivalence is also presented to answer the questions of the study.

\section{METHODS}

The study uses descriptive qualitative in which the results are presented in form of analysis. "Qualitative data analysis involves organizing, accounting for and explaining the data; in short, making sense of data in terms of the participants' definitions of the situation, noting patterns, themes, categories and regularities" (Cohen et al., 2007, p. 461). In the beginning, the transcriptions of both versions and back translation were made to support the analysis. Those transcriptions were afterward used to identify cultural filters through five dimensions of House. They are cultural filters in terms of directness, orientation towards self versus orientation towards other, orientation towards content versus orientation towards addressee, explicitness, and ad-hoc formulation 
versus verbal routines. Each dimension were continued to be identified in its functional equivalence according to Nida (1964). The sentences which did not achieve functional equivalence belonged to the non-equivalent data. The researcher revealed the causes and finally, they were tabulated in the table. After getting to know the amount of each dimension, the researcher took some data samples to analyze and get a deeper understanding.

\section{RESULTS AND DISCUSSIONS}

This part discusses the results of the research and give the detail explanation about the findings.

\section{Cultural Filter in Terms of Directness}

The first dimension proposed by House was directness and indirectness. There were two transformations, namely the transformation of indirectness to directness and the transformation of directness to indirectness. The amount of cultural filter of indirectness to directness was 20, while the amount of another transformation was 10 . Furthermore, the phrases or dialogues found in this dimension achieved functional equivalence according to Nida's theory. The example is given below.

(1) a. Chicken Little:I figure, hey, you could give me some pointers!

b. Chicken Little: Mungkin Ayah bisa memberiku tips! (Maybe you could give me tips!)

According to the example above, the English version (1a) showed that it used indirectness strategy, while in translation version it used directness, by omitting the phrase 'I figure'. The translator thought that it was not necessary to translate since the context and the message was clear enough for readers. It showed that the speaker preferred to express utterances indirectly rather than directly. It was suitable with House, as she found out that English tended to speak indirectly. On the contrary, Indonesians like to hide their emotion in order to avoid offensiveness (Geertz, 1973). It resembles that Indonesian actually communicates indirectly. The statement is the opposite of the result in which the translator mostly used a direct communication style. It was not a problematic one because House (2015) stated that "cultural filter nonobjectively and consequently undertook changes on the situational dimensions" (p. 59).

On the contrary, the example below shows the cultural filter in terms of directness to indirectness.

(2) a. Chicken Little: Everybody, I'm telling the truth, Dad! I'm not making this up! You gotta believe me this time!

b. Chicken Little: $A k u$ bicara yang sebenarnya! Ayah! Aku tidak berbohong! Kali ini percayalah, Ayah! (I'm telling the truth! Dad! I'm not lying! Believe me for this time, Dad!)

The sentence belonged to this kind of orientation due to the differences of culture in terms of politeness in each country. The notion is called honorific terms, in which a word or a title can determine respect, politeness, and social level (Nordquist, 2020). English speakers are accustomed to directly referring the interlocutors regardless of the status. It is opposite to Indonesians which always pay attention to the status of the addressee. Besides, Eastern families usually keep their politeness as a habit to respect older people (Puspakirana \& Setiawan, 2014). Therefore, instead of translating 'kamu' in datum (2b), the translator preferred using honorific terms by saying 'Ayah' to show the politeness of Chicken Little to his father. To sum up, the translation eventually reached the functional equivalent even though there was a gap in culture.

\section{Cultural Filter in Terms of Orientation towards Self versus Orientation towards Other}

The second dimension was orientation towards self to orientation towards other. Both transformations are realized by the use of pronoun. On the one hand, orientation towards self is identified by pronoun 'I' and 'we' which 
refer to the first person in the dialog. On the other hand, orientation towards other is identified by the third person in the dialog, like 'you', 'he', 'she', 'they', and 'it/this/that/there'. According to it, only 3 data were showing the cultural filter of orientation towards self to orientation towards other. Moreover, all of them were found to reach functional equivalent. By contrast, no data was showing the cultural filter of orientation towards other to orientation towards self. The findings turned out that some dialogs had a transformation from other to other instead. It was not a big matter since both author and translator might have preferences to adjust and cope with each dialog.

(3) a. Buck Cluck: Okay, thank you for talking to me! I'll take care of my son!

b. Buck Cluck: Oke, terima kasih telah menjelaskannya. Akan kuurus anakku. (Okay, thank you for explaining it. I'll take care of my son.)

It was obvious that in datum (3a), the original version used object pronoun 'me' to emphasize the statement. However, it was not translated as the way it was. The TT in (3b) omitted pronoun 'me' and opted it into 'menjelaskannya' which focusing only pronoun 'it'. It reflects Indonesian culture as people will put family as the first priority rather than individuals (Communicaid, n.d). In the dialog, it seemed clear enough that the teacher only talked to Mr. Cluck so that the readers would still understand the translation. Besides, having suffix 'nya' is common in Indonesian at the end of the word. Nevertheless, both versions have correlated meaning regarding context of function and situation, so it could be concluded that they achieved functional equivalent.

\section{Cultural Filter in Terms of Orientation towards Content versus Orientation towards Addressee}

The third dimension proposed by House was orientation towards content versus orientation towards addressee. The dimension is used when both the author and the translator opt to focus on the content and message or emphasizing the addressees. According to the findings, there were 111 data found using this dimension. The researcher identified 24 data using the transformation of orientation towards content to orientation towards addressee and all of them have achieved functional equivalence. The second transformation is orientation towards addressee to orientation towards content. Unlike the previous one, this transformation got a lot of data, which was 87 . However, not all data have fulfilled functional equivalence as 3 data were found to have nonequivalence. The following is the example of the transformation of orientation towards content versus orientation towards addressee.

(5) a. A mommy: Yes, it is the crazy little chicken! You're so smart. Let's not make eye contact!

(5) b. Ibu: Benar! Ayam kecil yang gila. Kamu sangat cerdas. Jangan lihat dia. (Right! The crazy chicken little. You're so smart. Don't see him!)

In the English version, it was clear that the one the mummy and her son were talking was Chicken Little. She said 'it is the crazy little chicken' when Chicken Little was passing. In the next utterance, the mummy did not mention his name again since they knew that it referred to Chicken Little. Instead, she emphasized the talk by giving a command to her son not to make eye contact with Chicken Little. Meanwhile, in the Indonesian version, the pronoun 'him' was there to make sure that Chicken Little was being talked and the readers got their understanding. To conclude, nothing was confusing to understand both versions because the context of function and situation was suitable with each other. Therefore, datum 5 was classified as functional equivalence.

(6) a. Teacher: Time out! We need the nurse!

(6) b. Guru: Stop! Panggil perawat! (Stop! Call the nurse!)

Datum 6 belonged to the transformation of orientation towards addressee to orientation 
towards content Here, the English version clearly focused on the use of pronoun 'we'. Therefore, the sentence was considered as a statement since it referred to the addressee. Instead of using literal meaning translation, the translator focused on the content by neglecting the pronoun. Finally, it created an imperative meaning which was more understandable for children. Despite the missing pronoun in TT, the translation version could achieve functional equivalence since it presented the similarity of context of function and situation with the original one.

\section{Cultural Filter in Terms of Explicitness versus Implicitness}

The fourth cultural filter revealed in this study was cultural filter in terms of explicitness and implicitness. It was gotten that 31 data were using the fourth dimension. The transformation from explicitness to implicitness had 17 occurrences while the transformation from implicitness to explicitness had 14 occurrences. On the other hand, there were 9 data found regarding non-equivalent.
(7) a. Commentator: There's excitement in the air, ladies and gentlemen... it's been two decades since Oakey Oaks has beaten long time rivals, Spud Taters...

(7) b. Komentator: Semua bergembira, para penonton... sudah dua dekade berlalu sejak Oakey Oaks mengalahkan musuh bebuyutannya, Spud Valley Taters... (Everybody's happy, ladies and gentlemen... it's been two decades since Oakey Oaks has beaten their long time rivals, Spud Taters...)

It was stated 'There's excitement in the air, ladies and gentlemen'. If it was translated literally, the meaning of the expression would sound unusual for children. Thus, the translator attempted to find how to express joy in general. The phrase 'Semua bergembira, para penonton' was suitable and more common in Indonesian. Regardless the transformation, both Source
Text and Target Text fulfilled the functional equivalence.

The opposite of explicitness to implicitness was indeed the cultural filter of implicitness to explicitness. Here, the ST or the author of the comic preferred to uttered sentences generally. In other word, the sentences were not clearly or directly stated.

(8)a.Chicken Little: But... but... bigaccorflevelfla ... bigaccorflevelfla

(8)b. Chicken Little: Tapi... tapi... belb bla belb bla... belb bla belb bla... (But... but... bigaccorflevelfla... bigaccorflevelfla)

The dialog occurred when the journalists asked him about how he mistook a stop sign for an acorn. It made Chicken Little nervous and confused to respond. Therefore, he seemed stuttering and reflected by random talks like 'bigaccorflevelfla'. In fact, such thing was identified as implicitness since children would wonder what the dialog talked about. It took effort for them to guess the meaning. Hence, the translator changed it into a more familiar way to express someone who was in a confusing situation. To sum up, this datum was categorized as non-equivalent because the original text was not appropriate with the context of situation and function as well.

The result is different with House, as English native speakers prefer to communicate implicitly. It is affected by the culture where they tend to be introverted regarding their personal issues. Moreover, they will keep their personal life and stuff toward society. Thus, it is common if they choose not to express things clearly. On the other hand, the translator who was Indonesian carried out the version relating with Indonesian communication style. They like to express explicitly because everybody has the rights to speak up. It is similar to German in which "they tend to be very explicit and focusing on the content of a message rather than on the addressee" (Watzky, 2013, p. 70). At last, there is no fixed communication style as the speakers needed to adjust the target readers in order to convey the messages clearly. 
Cultural Filter in Terms of Ad-hoc Formulation versus Verbal Routines

The fifth dimension discussed in this study was orientation towards verbal routines versus ad-hoc formulation. The transformation of verbal routines to ad-hoc formulation appeared 9 times. However, one of them was found as non-equivalent. On the other hand, the transformation of ad-hoc formulation to verbal routines obtained 6 utterances and three of them could not also reach functional equivalent.

Cultural filter of verbal routines to adhoc formulation occurred when the author preferred to use daily language which was more common to a kind of figurative language in the dialog. Meanwhile, the translator opted for specific terms in Indonesian.

(9) a. Abby Mallard: Now that's closure!

(9) b. Abby Mallard: Itulah hati ke hati

(That's heart to heart!)

Datum (9a) belonged to verbal routine as the phrase was common and familiar in our daily life. However, the meaning on datum (9b) was inappropriate because there was no correlation between the original and translation version. 'Closure' meant 'penutupan' yet it was translated in form of figurative language 'hati ke hati'. It was because the translator could not find the closest meaning over the original version. To solve it, (s)he looked into the context to make a relatable meaning. The situation showed that Chicken Little was on fire to return the alien kid back and suddenly kissed Abby. Abby felt so glad about it and said the phrase. It actually created misunderstanding since 'closure' could indicate that Chicken Little was leaving his place, but the translator interpreted it as Abby's feeling after being kissed by him. Hence, it was categorized as one of non-equivalent translations in this transformation since the context of situation of both versions were not the same. Probably the failure of translating figurative language occurred because of some reasons. Hartono (2012) reveals that a translator has difficulties every time s(he) translates literary works, such as the inability to understand complex sentences and find the closest natural equivalence regarding the cultural differences.

(10) a. Chicken Little: Good people of Oakey Oaks... though at times it may feel like the sky is falling around you... never give up, for every day is a new day!

(10) b. Chicken Little: Penduduk Oakey Oaks yang baik... meskipun kadang keadaan sangat sulit... jangan menyerah. Setiap hari adalah hari baru! (Good people of Oakey Oaks... though sometimes the situation is very difficult... don't give up. Every day is a new day!)

According to a datum (10a), it could be seen that the author used figurative language within the phrase 'the sky is falling around you' to express the hard times people had one day. Meanwhile, in Indonesian version it was stated with 'keadaan sangat sulit'. Here the translator made an appropriate translation which would be easily understood by the readers. Indeed, both original and translation versions reached the functional equivalent since the Target Text resembled the figurative language used in the Source Text though it was in non-figurative language form.

\section{Functional Equivalence}

After identifying the cultural filter by using five dimensions, the last stage to answer the research question in this study was identifying functional equivalence proposed by Nida (1964). A datum belongs to functional equivalence when the original version and translation have the similarity in terms of context of situation as well as context of function.

As the requirement was determined, it was not a hard thing to identify which datum did not achieve functional equivalence or rather non-equivalence. There were 215 cultural filters found in the comic. However, out of 215 data, there were 15 dialogues which identified as 
non-functional equivalence. They occurred only in dimension orientation towards content versus orientation towards addressee, explicitness versus implicitness, and ad-hoc formulation versus verbal routines. The causes of non-equivalence were mostly because of the translator's misunderstanding about the context, therefore it made a different point of view between the author and translator.

According to the analysis, the cultural filter of orientation towards content versus orientation towards addressee showed 3 data that belonged as non-equivalent. The translator misinterpreted the ST that in the end, the translation had different function. Moreover, the translation seemed unrelated to the preceding and subsequent dialog. Therefore, the situation told in the comic was quite confusing because of its irrelevance.

The next dimension which was found to have non-equivalent was orientation towards explicitness versus orientation towards implicitness. This sort of cultural filter obtained 9 data. One of them happened because the translation was irrelevant to the original version. The exact translation of the English version should be 'dimana semangatnya disini', on the other hand, it was written with 'ada apa ini' in the Indonesian version. Therefore, the datum belonged to non-equivalent since the context of situation of both versions were different.

In the dimension ad-hoc formulation versus verbal routines, there found 3 utterances identified as non-equivalence. It probably happened because of the misunderstanding in translating figurative languages. The phrase 'where's your head' which probably meant 'dimana pikiranmu' was translated into 'bagaimana, sih'. In fact, it would definitely confuse the readers as it did not describe the situation at that time. Although the translator was able to adjust with the situation in the comic, still both versions had different context of function. The original version was intended to ask something, while the translation was likely showing annoyed expression.

\section{CONCLUSIONS}

To sum up, the study of cultural filter of children comic Chicken Little: The Sky is Falling obtained five dimensions, they were orientation towards directness versus indirectness, orientation towards self versus other, orientation towards addressee versus content, orientation towards explicitness versus implicitness, and orientation towards ad-hoc formulation versus verbal routines. The result showed that out of 88 culturally filtered data, there were 190 data found using those dimensions. Following the results, it could be concluded that the translation of comic Chicken Little: The Sky is Falling successfully applied cultural filter in most of its dialogues. It portrayed that the translator attempted to adjust the Source Language with many cultural differences inside to be similar with the Target Language.

Along with the discussion, it led to another identification in which the translator used covert translation. As it was explained previously, covert translation focused on the Target Language during the translation process. It is the type of translation which do not depend on the Source Language to make another version of text.

In addition, the result of cultural filter analysis showed that most of the translations were successfully achieved functional equivalence. As the theory stated, one could fulfill functional equivalence as long as the translation created similar context of situation and function with the original one.

\section{REFERENCES}

Bassnet, S. (2002). Translation studies ( $3^{\text {rd }}$ ed.). Routledge.

Baumgarten, N., House, J., \& Probst, J. (2004). English as lingua franca in covert translation processes. The Translator, 10(1), 83-108.

Cohen, L., Manion, L., \& Morrison K. (2007). Research methods in education ( $6^{\text {th }}$ ed.). Routledge Taylor \& Francis Group. 
Communicaid. (n.d.). Indonesia cross-cultural and language training. Retrieved October 10, 2020.

Geertz, C. (1973). The interpretation of cultures. Basic Books, Inc.

$\mathrm{Hu}, \mathrm{Y}$. (2000). The sociosemiotic approach and translation of fiction. Translation Journal, $4(4)$.

Hartono, R., \& Priyatmojo, A. S. (2015). Tripartite cycle model (TCM): An alternative solution for translating novels from English to Indonesian. Arab World English Journal, 6(4), 182-198.

Hartono, R. (2012). Translation problems of idioms and figurative languages from English into Indonesian. ELTL Conference Proceedings, 355-365.

House, J. (2015). Translation quality assessment, past and present. Routledge Taylor \& Francis Group.

House, J. (2016). Translation as communication across languages and cultures. Routledge Taylor \& Francis Group.

Ismail, A., \& Hartono, R. (2016). Errors made in google translate in the Indonesian to English translations of news item texts. Journal of English Language Teaching, 5(2), 1-6.

Kuncoro, H., \& Sutopo, D. (2015). The ideology in the Indonesian-English translation of cultural terms. English Education Journal, 5(2), 8-13.

Lovihandrie, H., Mujiyanto, Y., \& Sutopo, D. (2018). Translation strategies used by Lingliana in translating taboo words in Sylvia Day's Bared to You. English Education Journal, 8(2), 208-220.

Mujiyanto, Y. (2011). Non-equivalence in the English-to-Indonesian translation of behavioral clauses. Language Circle: Journal of Language and Literature, 6(1), 57-71.

Nida, E. (1964). Toward a science of translating: With special reference to principles and procedures involved in Bible translating. E.J. Brill.
Nordquist, R. (2020). How honorifics are used in english. Retrieved February 5, 2021.

Prasetyo, J., \& Nugroho, A.B. (2013). Domestication and foreignization and their impacts to translation. Language Circle: Journal of Language and Literature, 8(1), 1-10.

Puspakirana, I., \& Setiawan, S. (2014). A study of cross-cultural understanding of showing anger in Iindonesian and Australian families. Language Horizon Journal, 2(2).

Rupiah, S.N., \& Hartono, R. (2017). Shift in the Indonesian translation of English noun phrases in barbie short stories. English Education Journal, 7(3), 227-236.

Sari, M. P., \& Yuliasri, I. (2017). Translation procedures of physics terms in the physics bilingual book for Senior High School Year XI. Journal of English Language Teaching, 6(2), pp. 102-115.

Thije, J. D., \& Tempel, M. (2010). The appreciation of cultural and linguistic adjustments in multilingual museum audio tours by international tourists. Journal of Multicultural Discourses. Netherlands: Department of Dutch, Universiteit Utrecht.

Vinay J. P., \& J. Darbelnet. (2000). A Methodology of Translation. Routledge.

Watzky, S. (2013). German-English communication: Across-cultural challenge. Journal of International Students, 3(1), 70-71.

Wijayanti, D., \& Mirahayuni, N.K. (2014). An analysis of translation strategies for nonequivalence used in Lian Gouw's novel Only A Girl and its translation version Only A Girl-Menantang Phoenix. Parafrase, 14(1), 31-37.

Yinhua, X. (2011). Dynamic equivalence: Features and merits. Theory and Practice in Language Studies, 1(9), 1253-1255.

Yuliasri, I. (2016). Translation techniques and pragmatic equivalence in Indonesian translation of humorous utterances in the Walt Disney's Donald Duck comics. International Seminar Prasasti III: Current Research in Linguistics, 409-414. 
Angga Karismawati, et al./ English Education Journal 11 (2) (2021) 308-317

Yuliasri, I. (2017). Translators' censorship in English-Indonesian translation of
Donald Duck comics. Indonesian Journal of Applied Linguistic, 7(1), 105-116. 